\title{
Mitochondria-Centric Activation Induced Cell Death of Cytolytic T Lymphocytes and its Implications for Cancer Immunotherapy
}

Arvind Chhabra

University of Connecticut School of Medicine and Dentistry

Follow this and additional works at: https://opencommons.uconn.edu/uchcres_articles Cart of the Oncology Commons

\section{Recommended Citation}

Chhabra, Arvind, "Mitochondria-Centric Activation Induced Cell Death of Cytolytic T Lymphocytes and its Implications for Cancer Immunotherapy" (2010). UCHC Articles - Research. 216.

https://opencommons.uconn.edu/uchcres_articles/216 


\title{
Mitochondria-Centric Activation Induced Cell Death of Cytolytic T Lymphocytes and its Implications for Cancer Immunotherapy
}

\author{
Arvind Chhabra \\ Department of Medicine, University of Connecticut Health Center, Farmington, Connecticut, USA.
}

\begin{abstract}
Premature death of the adoptively transferred cytolytic T lymphocytes (CTL) by means of activation induced cell death (AICD) represents one of the major constraints in devising an effective anti-cancer immune intervention strategy. Understanding the mechanism of AICD is, therefore, critical for developing methods to interfere with this death process. Although the existing paradigm on AICD centers around the initiation of the cascade of events originating from the engagement of death receptors leading to the activation of effector caspases and eventually resulting in cell death, recent findings have questioned the universal role of caspases as the cell death executioners. We here review our current understanding of the contribution of caspasedependent and caspase-independent death executioners in AICD of T cells. We will also discuss the involvement of mitochondria-centric death pathway in AICD of human tumor associated antigen specific primary CTL and its implications in cancer immunotherapy.
\end{abstract}

\section{Keywords}

Cancer; Immunotherapy; Melanoma

\section{Introduction}

Since the identification of first human tumor associated antigenic epitope in melanoma model [1], a substantial progress has been made towards understanding the molecular and cellular basis of the generation of a productive anti-tumor immune response. Numerous cancer-associated antigens have been in different human tumor models, CD8+ tumor antigen specific $\mathrm{T}$ cells have been recognized as the key facilitators of the adaptive antitumor immune response and the molecular signals that modulate T-cell activation, effector function and memory generation have also been characterized in greater details. Since most human tumors are MHC class I positive but MHC class II negative [2-4], i.e. CD8+ T cells can target them but CD4+ T cells cannot, a great majority of the current cancer immunotherapy strategies are aimed at activation and expansion of tumor antigen specific CD8+ cytolytic T lymphocyte (CTL) precursors.

Interestingly, most current immunotherapy approaches can be put into two broad categories, active specific immunization and adoptive immunotherapy. Of these, active immunization

\footnotetext{
(C) 2010 Elsevier Ltd. All rights reserved.

Communicating Author Information: Department of Medicine, University of Connecticut Health Center, Farmington, Connecticut, USA-06030. arvindac@yahoo.com, Phone: 860-679-1447.

Publisher's Disclaimer: This is a PDF file of an unedited manuscript that has been accepted for publication. As a service to our customers we are providing this early version of the manuscript. The manuscript will undergo copyediting, typesetting, and review of the resulting proof before it is published in its final citable form. Please note that during the production process errors may be discovered which could affect the content, and all legal disclaimers that apply to the journal pertain.
} 
involves the administration of DC based vaccine regimens, while adoptive immunotherapy involves the administration of patient specific ex-vivo expanded anti-tumor cytolytic immune effectors. Although both these approaches have been shown to produce a productive clinical response, a greater degree of success has been achieved with adoptively transferred tumor antigen specific killer $\mathrm{T}$ cells than with the active immunization based approaches [3]. One possible explanation for this could be the fact that the vaccine regimens administered in active immunization based approaches have to overcome multiple redundant regulatory mechanisms of the host immune system to facilitate the generation of an effective anti-tumor CTL response, while the quality of the anti-tumor immune effectors to be administered under adoptive immunotherapy could be better controlled. However, it is now well-established that the mere presence of the anti-tumor $\mathrm{T}$ cell in cancer patients, generated in-vivo through active specific immunization based approaches or adoptively administered ex-vivo expanded CTL, does not always guarantee an objective clinical response [3,5]. Therefore, a critical analysis of different mechanisms hindering the success of immune based cancer therapy approaches is required to develop potent strategies to effectively target the growing tumor.

Among the possible reasons for the low success rate with CTL based immunotherapy includes the premature elimination of anti-tumor CTL by means of epitope specific AICD upon encountering their target antigen on tumor cells [6]. Although this concept has been extensively looked at under the "tumor counter attack" hypothesis $[7,8]$, however, these studies envisioned Fas-Fas ligand engagement as the sole mechanism of the deletion of tumor antigen specific CTL. Interestingly, recent findings from different laboratories, including ours, have questioned the universal role of death receptors as the key initiators and caspases as the sole executioners of cell death in T cells in general, and in human tumor antigen specific primary CTL in particular [9-13]. It has been shown that the death of human tumor antigen specific $\mathrm{T}$ cells upon exposure to their cognate antigens, is an intrinsic caspase-independent process $[9,10]$. We here try to reconcile the recent findings with the existing paradigm on T cell death and update our understanding of the mechanism of AICD in human tumor antigen specific primary $\mathrm{T}$ cells. Table- 1 summarizes the key advances in $\mathrm{T}$ cell based cancer immunotherapy field and the obstacles limiting the success of current immunotherapy approaches.

\section{Contribution of caspase-dependent and caspase-independent cell death pathways in AICD of T cells}

Figure. 1 schematically shows the kinetics of an antigen specific $\mathrm{T}$ cell response. As shown, $\mathrm{T}$ cells expand enormously upon recognition of their cognate antigenic epitope in context with the professional antigen presenting cells (APC). However, mechanisms such as programmed cell death (PCD) and AICD ensure that the excess antigen specific T cells are cleared off, once the antigen load has subsided, to maintain the immune homeostasis. As a result, a great majority of antigen specific effector $\mathrm{T}$ cells die through these mechanisms, leaving behind a very small population of memory T cells. Although PCD and AICD are essential host immune homeostasis mechanisms, a premature elimination of adoptively administered or in-vivo generated tumor antigen specific $\mathrm{T}$ cells through epitope specific AICD could limit the efficacy of T cell based cancer immunotherapy strategies. Therefore, it is a reasonable expectation that by interfering with the AICD process, the clinical efficacy of anti-tumor $\mathrm{T}$ cells could be significantly improved.

Interestingly, the seminal studies on AICD in T cells were done in T cell hybridomas, Jurkat cells, T cell lines and TCR and/ or super antigen-driven T cells [14,15]. These studies were followed by studies in $l p r$ and $g l d$ mice lacking Fas and FasL respectively, that showed excess lymphocytes and highlighted the critical requirement of death receptors (DR)- 
mediated signals in leukocyte survival [16,17]. Death-receptors (e.g. Fas, TNF-R1 etc.) are surface expressed receptors that contain a conserved domain called death domain (DD) on their cytoplasmic domains that transmits the signal received from the extra-cellular milieu. The engagement of the death receptors with their ligands leads to the recruitment of adaptor proteins, Fas-associated death domain (FADD) and TNF-receptor 1-associated death domain (TRADD), via interactions between their death domains and formation of a death-inducing signaling complex (DISC) $[18,19]$. Through homotypic interaction of death effector domain (DED), FADD causes the recruitment and activation of caspase- 8 followed by the activation of effector caspase, caspase-3, leading to the DNA degradation and ultimately cell death $[18,19]$.

All these studies led to the current paradigm on AICD of T cells that states that the initiation of cascade of events originating from the engagement of death receptors leads to the activation of effector caspases and culminates in cell death. However, recent reports have not only questioned the indispensability of death receptors and caspases in T cell death [12,20-22], caspases have also been shown to play key role in cell proliferation [23-25]. T cells from $l p r$ and $g l d$ mouse have also been shown to undergo caspase-independent death [26], and Fas has also been shown to play critical role in caspase-mediated cell death via recruitment of FADD and caspase- 8 and caspase- 10 followed by activation of caspase- 3 ; it has also been implicated in execution of the caspase-independent cell death via recruitment of RIP molecule, under some conditions $[19,27,28]$. The over expression of caspaseinhibitor FLIP in mouse has also been shown to increase the resistance of their T cells to Fas mediated death, but it did not result in the increased accumulation of T cells. Furthermore, mice lacking caspases-1, 2, 3, 6, 9, 11, and 12 have all been shown to possess a hematopoietic system of normal size and composition, while caspase- $8^{-/-}$embryos have been shown to possess abnormally low numbers of blood cells (reviewed in [29]). Although these results could be explained by a possible redundancy in the use of these caspases in the developmentally programmed death of leukocytes, however, alternatively, it could also mean that the caspases are not the sole determinants of survival of immune cells in physiology.

Taken together, these reports strongly recommend a careful re-examination of the contribution of caspase-independent death pathways in T cell survival and maintenance of immune homeostasis. This is especially important with respect to the human antigen specific primary $\mathrm{T}$ cells, since seminal studies on AICD in T lymphocytes were carried out with transformed cell lines and with the addition of cytokines/ drugs [14,15,30,31]. These findings could not be confirmed at that time in antigen specific human primary $\mathrm{T}$ cells, due to the unavailability of the methods to generate sufficiently large numbers of antigen specific $\mathrm{T}$ cells for systematic biochemical analyses, and also due to the unavailability of the technologies and tools to characterize human antigen specific primary T cells. Even after the availability of such tools and methodologies not enough emphasis was put on such studies since this was not considered to be or immense importance, however, with the realization that the AICD might be a key limiting factor hindering the success of current $\mathrm{T}$ cell based cancer-immunotherapy approaches, these studies becomes very important. Furthermore, with recent reports suggesting the existence of a caspase-independent death pathway in regulation of T cell survival and maintenance of immune homeostasis, especially in regulation of epitope specific AICD in human tumor antigen specific T cells [9-13], these studies become even more critical. A clear understanding of the mechanism of AICD in human tumor reactive CTL will allow us to interfere with this process and improve the efficacy of the $\mathrm{T}$ cell based cancer-immunotherapy protocols. Table- 2 summarizes the key developments that have led to the current understanding of the $\mathrm{T}$ cell death, in general, and AICD in human anti-tumor T cells, in particular. 


\section{Involvement of Mitochondria-Centric Death Pathway in AICD}

Mitochondria has received much attention for its role in regulation of the cell death process in various systems including human primary CTL, since it harbors many apoptotic death executioners, that are involved in caspase-dependent as well as caspase-independent cell death pathways [10,32-34]. Both extrinsic (DR-mediated) as well as intrinsic pathways of cell death converge upon mitochondria and mitochondria plays a crucial role in execution of cell death by caspase-dependent pathway as well as by caspase-independent pathways $[32,34,35]$. The most well studied apoptotic factor released from the permeabilized mitochondria is the respiratory component cytochrome-c [32]. Upon release into the cytoplasm, cytochrome-c activates Apaf- 1 and triggers the caspase cascade leading to the activation of executioner caspase, caspase-3 [32]. Activated caspase-3 then cleaves the inhibitor of caspase-activated DNase (ICAD), which allows caspase-activated DNase (CAD) to enter the nucleus and lead to the oligonucleosomal DNA fragmentation [36,37]. More recently, mitochondrial membrane permeabilization in response to apoptotic signals has been shown to release the proapoptotic factors, such as Smac/ Diablo and HtrA2/ Omi [3840]. These proteins facilitate the caspase activation by binding to and inhibiting the function of members of the inhibitor of apoptosis protein (IAP) family [41,42]. Interestingly, HtrA2/ Omi also possess a serine protease activity, which contributes to the caspase-independent cell death processes [40].

Mitochondria also harbor death inducers such as apoptosis-inducing factor (AIF) and Endonuclease G (EndoG), that mediate cell death in caspase-independent manner [43,44]. In healthy cells, AIF is retained in the mitochondria where it performs an oxidoreductase function based on the presence of a FAD binding domain in the $\mathrm{N}$-terminus and its redox activity [45].

However, similar to the bifunctional role of cytochrome-c, when AIF is released from the mitochondria in response to the apoptotic stimuli it becomes an active executioner of the cell death. Following an apoptotic stimulus, AIF translocates to the nucleus and trigger the chromatin condensation in a caspase-independent manner [11,13,43,46,47]. Although it was earlier believed that a breach in mitochondrial permeability results in complete breakdown of mitochondrial integrity resulting in the release of mitochondria resident apoptosis inducing proteins, recent findings have shown that this is a highly regulated process, and the mitochondrial death effector proteins can also be selectively released without any concomitant release of cytochrome-c [48-50].

Interestingly, the contribution of caspase-independent mitochondria-centric death pathway in AICD of human primary T lymphocytes has not yet been systematically examined. Towards this, our recent work on AICD in human melanoma model suggesting the existence of a tightly regulated mitochondria-centric death pathway in regulating the AICD of human tumor antigen specific primary CTL [10], is quite encouraging. We have found that the AICD of human melanoma-associated antigenic epitope, MART- $1_{27-37}$, specific primary CTL is associated with the selective release of mitochondrial death effector protein, AIF [10], and that this death is a JNK activation driven, caspase-independent, DR-independent process. Figure. 2 schematically summarize our current understanding of the caspasedependent and caspase-independent pathways of cell death in T cells (Fig.2).

\section{Regulation of Mitochondrial Permeability During AICD Process}

Mitochondria are surrounded by a double membrane, which divides them into two subcompartments. A transmembrane channel, called the permeability transition pore or PTP, is formed at the contact sites between the inner (IMM) and outer mitochondrial membrane (OMM). The core components of PTP are the voltage-dependent anion channel (VDAC) in 
the OMM and the adenine nucleotide translocator (ANT) in the IMM. VDAC makes the OMM permeable to most small molecules ( $<5 \mathrm{kDa}$ ), allowing free exchange of respiratory chain substrates [51,52]. Breach in mitochondrial permeability is the key event during mitochondrial cell death pathway, resulting in release of apoptotic proteins, such as cytochrome-c, AIF, Endo-G etc.

The Bcl-2 family pro- and anti-apoptotic proteins function as "arbiters" of mitochondrial membrane integrity [53]. Bcl-2/Bcl- $\mathrm{X}_{\mathrm{L}}$, the prototypic anti-apoptotic proteins maintain mitochondrial membrane integrity and function as anti-apoptotic proteins by regulating the mitochondrial permeability transition pore complex (PTPC) [54,55]. Bak and Bax, the prototypic pro-apoptotic Bcl-2 family members affect the mitochondrial outer membrane potential (MOMP) by regulating the VDAC activity of the mitochondrial permeability transition pore $[54,55]$ while the pro-apoptotic BH3-only members such as Bid and Bim appear to induce oligomerization of Bax and Bak resulting in the release of mitochondrial apoptogenic factors [55,56]. P53 has also been recently shown to influence the integrity of the mitochondria, in a post-translational manner, by interacting with the $\mathrm{Bcl}$ family proteins $[57,58]$. Studies in mouse models have clearly established that the Bcl-family proteins play a critical role in the survival of T lymphocytes [53,59,60]. Similar to the studies in $l p r$ and gld mouse models [16,17], abnormalities in the Bcl-2-regulated signaling pathways, such as the expression of a $b c l-2$ transgene, loss of BH3-only protein Bim, or a combined deletion of Bax and Bak, have all been shown to cause extensive lymphoid and myeloid cell accumulation [reviewed in [61]]. However, the distinct nature of the death receptor-induced and Bcl-2-regulated pathways of apoptosis is highlighted by the observations that the expression of $b c l-2$ transgene in $l p r$ or $g l d$ mice enhances lymphadenopathy $[62,63]$.

Interestingly, while over-expression or loss of Bcl-2 family members can lead to hyperplasia or hypoplasia of hematopoietic cell populations, to date none of the knockout mutations of any of the caspases have had such dramatic effects in the hematopoietic system. Since Bclfamily proteins play a critical role in the $\mathrm{T}$ cell survival and they function as key regulators of the mitochondrial membrane integrity, it is critical to systematically examine their role in the regulation of mitochondria-centric pathway in AICD of human tumor antigen specific primary $\mathrm{T}$ cells.

\section{Involvement of JNK in Regulation of Mitochondira-Centric AICD of T Cells}

The c-Jun N-terminal kinases were first identified in 1990 as the cycloheximide activated protein kinases in rodent liver [64]. Soon after, it was found that the JNK kinases are activated in response to a wide array of stress conditions, and it is now well-established that JNK plays a critical role in stress induced apoptosis [65], neuronal cell apoptosis [66] and also in the central deletion of T cells [67-69]. JNK is known to have ten isoforms that are encoded by alternative splicing of three genes, JNK1, JNK2 and JNK3 [70]. JNK is activated by dual phosphorylation in response to a variety of apoptotic stimuli, for example, osmotic stress, redox stress, growth factor withdrawal, radiation etc., and the Bcl-2 family proteins have been shown to play key role in JNK mediated cell death pathways $[48,56,66,69,71,72]$. Bim has been shown to relay the apoptotic signal originating from JNK activation to the mitochondria and leads to release of apoptotic proteins [66,73]. JNKmediated phosphorylation of Bim results in Bax dependent apoptosis [73]. In addition, Bim has also been shown to participate in cell death process in a VDAC-dependent manner [74]. Bax and Bak are critical players in the JNK-dependent cell death pathway $[65,75]$.

Interestingly, we have found that the JNK activation is also a critical event in DRindependent, caspase-independent, mitochondria-centric AICD of human melanoma associated antigenic epitope, MART-1 $1_{27-35}$ specific primary CTL $[9,10]$. AICD in these 
cells is associated with a selective release of AIF without any concomitant cytochrome-c release that culminates in cell death mediated by a large- scale DNA fragmentation $[9,10]$; and blocking JNK activation prevents the mitochondrio-nuclear translocation of AIF, largescale DNA fragmentation and rescues these CTL from undergoing AICD [9]. Bim and Mcl-1 play significant role in this JNK activation driven AICD process ([9], and unpublished observations). Bim is upregulated in CTL undergoing AICD [9,76], and blocking JNK activation results in upregulation of Mcl-1 and prevention of AICD [9]. Taken together, these findings suggest that the JNK activation coupled with the Bcl-family proteins involvement modulates the mitochondrial membrane integrity in human tumor antigen specific primary CTL and controls the fate of these cells during the epitope specific AICD process.

It should also be mentioned here that JNK also plays a crucial role in the generation of $\mathrm{T}$ cell effector function, for example IFN- $\gamma$ production $[9,77]$. Therefore, it is critical to carefully define, how does activated JNK participate in the effector phase (IFN- $\gamma$ secretion) as well as in AICD process. Among the possibilities, the transient versus sustained JNK activation have been shown to exhibit a differential effect on cell death [78]. A similar mechanism can also be envisioned in this case and AICD in the primary CTL could result from a sustained JNK activation. It is also possible that the AICD in these cells result from the activation of the mitochondria-resident JNK, a possibility that has been proposed in JNK-driven apoptosis of other cell types [66,67]. Furthermore, it is also quite possible that the different isotypes of JNK are involved in the regulation of the effector function and the cell death pathways of antigen specific $\mathrm{T}$ cells.

Future studies should provide key insights on the mechanism of JNK activation driven AICD process in human tumor antigen specific T cells. Studies in tumor antigen specific CTL in cancer models other than melanoma and in tumor antigen specific $\mathrm{T}$ cells other than MART-1, and also in customized anti-tumor CTL generated through TCR engineering based approaches [79-81], are also needed to establish the generality of these findings. In addition, systematic studies are also needed in pre-clinical animal models to test the in-vivo superiority of AICD resistant antitumor CTL to target a growing tumor over natural CTL. The in-vivo efficacy of pharmacological inhibitor based and RNAi based approaches also need to be critically examined. Such studies are crucial since AICD mediators such as JNK can also have critical physiological role (IFN- $\gamma$ ) and knocking them down could have undesired consequences. Towards this, the availability of the clinical grade pharmacological inhibitors of JNK (reviewed in [82]) should make it feasible to address these issues in a straightforward manner. The outcome of these studies will be crucial to advance these laboratory findings into the clinic.

\section{Conclusion}

Since it conception, the tumor immunology field has made a great deal of progress and it has been clearly shown that, despite most tumor antigens being "self-antigens", it is indeed possible to generate productive anti-tumor tumor immune responses of dramatic clinical precision and efficacy. This is especially significant given the fact that even the most successful infectious disease vaccines have not been shown to be as effective against a progressive disease, as the immune based therapies targeting a progressing metastatic tumor. However, despite a great deal of progress having been made towards the identification of a range of tumor antigens, and towards the development of several novel strategies to target a growing tumor, the success with the current immune based cancer therapies has not yet met the expectations. 
Tumor immunologists have come to an agreement that the mere generation of an anti-tumor immune response is not going guarantee success, since the tumor microenvironment is quite a complex entity and a growing tumor employs multiple immune escape strategies to avoid/ counter the host immune surveillance mechanisms. For instance, tumors can down regulate antigen processing and presentation machinery (e.g., MHC molecules). Tumors can secrete inhibitory cytokines, such as IL-10 and transforming growth factor (TGF)- $\beta$, that can inhibit the dendritic-cell maturation, lead to the dysfunction of tumor infiltrating immune effectors and also could facilitate the recruitment of regulatory T cells (Treg). Many tumors express ligands that can interact with the infiltrating $\mathrm{T}$ cells to provide a negative stimulation, which inhibits or reduces the effector functions of tumor specific cytotoxic T lymphocytes. In addition, elimination of anti-tumor immune effectors by means of AICD is another factor hindering the success of the $\mathrm{T}$ cell based cancer immunotherapy approaches. Therefore, a successful immune based cancer therapy will not only have to guarantee the generation of a robust anti-tumor immune response, it will also have to ensure that the immune effectors generated are well equipped to counter/ overcome the immunosuppressive tumor microenvironment.

Towards this, the tumor reactive CTL that are less susceptible to undergo a premature AICD-mediated elimination sounds a reasonable strategy. Understandably though, a clear understanding of the TCR triggered cascade of events leading to the epitope specific AICD in human primary CTL is critical to interfere with the premature death of these tumor specific cytolytic $\mathrm{T}$ cells. In addition, with a considerable progress being made towards generating customized anti-tumor T cells through the TCR engineering based approaches, and also towards utilizing stem cells to generate patient specific $\mathrm{T}$ cells, a thorough understanding of the biology of human tumor antigen specific $\mathrm{T}$ cells will be very helpful in creating the next generation of anti-tumor immune effectors.

Finally, we would like to end our discussion by pointing out that with so many exciting happenings, the future of tumor immunology field could not have looked any more promising. It will be very interesting to see how soon all these advances can actually help the immune based cancer therapy to meet its clinical expectations.

\title{
Acknowledgments
}

Author thanks Dr Bijay Mukherji for helpful discussions and critical reading of the manuscript. Author also expresses heartfelt gratitude to all the contributors of the studies that are cited here and many more whom we could not cite, just because of the space limitation. It is their elegant work has that helped us bring this manuscript in its final form. Grant support from the Breast Cancer Alliance, Greenwich, Connecticut, is also warmly acknowledged.

\section{Commonly Used Abbreviations}

\author{
CTL Cytolytic T Lymphocytes \\ DC Dendritic Cells \\ AICD Activation Induced Cell Death
}

\section{References}

1. van der Bruggen $\mathrm{P}$, Traversari $\mathrm{C}$, Chomez $\mathrm{P}$, et al. A gene encoding an antigen recognized by cytolytic T lymphocytes on a human melanoma. Science. 1991; 254(5038):1643-1647. [PubMed: 1840703]

2. Mukherji B, Chakraborty NG. Immunobiology and immunotherapy of melanoma. Curr Opin Oncol. 1995; 7(2):175-184. [PubMed: 7756383] 
3. Rosenberg SA, Yang JC, Restifo NP. Cancer immunotherapy: moving beyond current vaccines. Nat Med. 2004; 10(9):909-915. [PubMed: 15340416]

4. Nouri-Shirazi M, Banchereau J, Fay J, Palucka K. Dendritic cell based tumor vaccines. Immunol Lett. 2000; 74(1):5-10. [PubMed: 10996622]

5. Terando AM, Faries MB, Morton DL. Vaccine therapy for melanoma: Current status and future directions. Vaccine. 2007

6. Whiteside TL. Tumor-induced death of immune cells: its mechanisms and consequences. Semin Cancer Biol. 2002; 12(1):43-50. [PubMed: 11926411]

7. Igney FH, Krammer PH. Immune escape of tumors: apoptosis resistance and tumor counterattack. J Leukoc Biol. 2002; 71(6):907-920. [PubMed: 12050175]

8. Igney FH, Behrens CK, Krammer PH. Tumor counterattack--concept and reality. Eur J Immunol. 2000; 30(3):725-731. [PubMed: 10741386]

9. Mehrotra S, Chhabra A, Chattopadhyay S, Dorsky DI, Chakraborty NG, Mukherji B. Rescuing melanoma epitope-specific cytolytic T lymphocytes from activation-induced cell death, by SP600125, an inhibitor of JNK: implications in cancer immunotherapy. J Immunol. 2004; 173(10): 6017-6024. [PubMed: 15528336]

10. Chhabra A, Mehrotra S, Chakraborty NG, Dorsky DI, Mukherji B. Activation-induced cell death of human melanoma specific cytotoxic $\mathrm{T}$ lymphocytes is mediated by apoptosis-inducing factor. Eur J Immunol. 2006; 36(12):3167-3174. [PubMed: 17109472]

11. Jaattela M, Tschopp J. Caspase-independent cell death in T lymphocytes. Nat Immunol. 2003; 4(5):416-423. [PubMed: 12719731]

12. Holler N, Zaru R, Micheau O, et al. Fas triggers an alternative, caspase-8-independent cell death pathway using the kinase RIP as effector molecule. Nat Immunol. 2000; 1(6):489-495. [PubMed: 11101870]

13. Kroemer G, Martin SJ. Caspase-independent cell death. Nat Med. 2005; 11(7):725-730. [PubMed: 16015365]

14. Ashwell JD, Cunningham RE, Noguchi PD, Hernandez D. Cell growth cycle block of T cell hybridomas upon activation with antigen. J Exp Med. 1987; 165(1):173-194. [PubMed: 3491868]

15. Shi YF, Sahai BM, Green DR. Cyclosporin A inhibits activation-induced cell death in T-cell hybridomas and thymocytes. Nature. 1989; 339(6226):625-626. [PubMed: 2786609]

16. Watanabe-Fukunaga R, Brannan CI, Copeland NG, Jenkins NA, Nagata S. Lymphoproliferation disorder in mice explained by defects in Fas antigen that mediates apoptosis. Nature. 1992; 356(6367):314-317. [PubMed: 1372394]

17. Takahashi T, Tanaka M, Brannan CI, et al. Generalized lymphoproliferative disease in mice, caused by a point mutation in the Fas ligand. Cell. 1994; 76(6):969-976. [PubMed: 7511063]

18. Sharma K, Wang RX, Zhang LY, et al. Death the Fas way: regulation and pathophysiology of CD95 and its ligand. Pharmacol Ther. 2000; 88(3):333-347. [PubMed: 11337030]

19. Schneider P, Tschopp J. Apoptosis induced by death receptors. Pharm Acta Helv. 2000; 74(2-3): 281-286. [PubMed: 10812970]

20. Maher S, Toomey D, Condron C, Bouchier-Hayes D. Activation-induced cell death: the controversial role of Fas and Fas ligand in immune privilege and tumour counterattack. Immunol Cell Biol. 2002; 80(2):131-137. [PubMed: 11940113]

21. Vercammen D, Vandenabeele P, Beyaert R, Declercq W, Fiers W. Tumour necrosis factor-induced necrosis versus anti-Fas-induced apoptosis in L929 cells. Cytokine. 1997; 9(11):801-808. [PubMed: 9367540]

22. Denecker G, Vercammen D, Steemans M, et al. Death receptor-induced apoptotic and necrotic cell death: differential role of caspases and mitochondria. Cell Death Differ. 2001; 8(8):829-840. [PubMed: 11526436]

23. Alam A, Cohen LY, Aouad S, Sekaly RP. Early activation of caspases during T lymphocyte stimulation results in selective substrate cleavage in nonapoptotic cells. J Exp Med. 1999; 190(12): 1879-1890. [PubMed: 10601362]

24. Kennedy NJ, Kataoka T, Tschopp J, Budd RC. Caspase activation is required for T cell proliferation. J Exp Med. 1999; 190(12):1891-1896. [PubMed: 10601363] 
25. Lamkanfi M, Festjens N, Declercq W, Berghe TV, Vandenabeele P. Caspases in cell survival, proliferation and differentiation. Cell Death Differ. 2006

26. Davidson WF, Haudenschild C, Kwon J, Williams MS. T cell receptor ligation triggers novel nonapoptotic cell death pathways that are Fas-independent or Fas-dependent. J Immunol. 2002; 169(11):6218-6230. [PubMed: 12444127]

27. Matsumura H, Shimizu Y, Ohsawa Y, Kawahara A, Uchiyama Y, Nagata S. Necrotic death pathway in Fas receptor signaling. J Cell Biol. 2000; 151(6):1247-1256. [PubMed: 11121439]

28. Vercammen D, Brouckaert G, Denecker G, et al. Dual signaling of the Fas receptor: initiation of both apoptotic and necrotic cell death pathways. J Exp Med. 1998; 188(5):919-930. [PubMed: 9730893]

29. Zheng TS, Hunot S, Kuida K, Flavell RA. Caspase knockouts: matters of life and death. Cell Death Differ. 1999; 6(11):1043-1053. [PubMed: 10578172]

30. Brunner T, Mogil RJ, LaFace D, et al. Cell-autonomous Fas (CD95)/Fas-ligand interaction mediates activation-induced apoptosis in T-cell hybridomas. Nature. 1995; 373(6513):441-444. [PubMed: 7530336]

31. Dhein J, Walczak H, Baumler C, Debatin KM, Krammer PH. Autocrine T-cell suicide mediated by APO-1/(Fas/CD95). Nature. 1995; 373(6513):438-441. [PubMed: 7530335]

32. Green DR, Reed JC. Mitochondria and apoptosis. Science. 1998; 281(5381):1309-1312. [PubMed: 9721092]

33. Finkel E. The mitochondrion: is it central to apoptosis. Science. 2001; 292(5517):624-626. [PubMed: 11330312]

34. Ravagnan L, Roumier T, Kroemer G. Mitochondria, the killer organelles and their weapons. J Cell Physiol. 2002; 192(2):131-137. [PubMed: 12115719]

35. Hildeman DA, Mitchell T, Kappler J, Marrack P. T cell apoptosis and reactive oxygen species. J Clin Invest. 2003; 111(5):575-581. [PubMed: 12618509]

36. Liu X, Zou H, Slaughter C, Wang X. DFF, a heterodimeric protein that functions downstream of caspase-3 to trigger DNA fragmentation during apoptosis. Cell. 1997; 89(2):175-184. [PubMed: 9108473]

37. Sakahira H, Enari M, Nagata S. Cleavage of CAD inhibitor in CAD activation and DNA degradation during apoptosis. Nature. 1998; 391(6662):96-99. [PubMed: 9422513]

38. Du C, Fang M, Li Y, Li L, Wang X. Smac, a mitochondrial protein that promotes cytochrome cdependent caspase activation by eliminating IAP inhibition. Cell. 2000; 102(1):33-42. [PubMed: 10929711]

39. Verhagen AM, Silke J, Ekert PG, et al. HtrA2 promotes cell death through its serine protease activity and its ability to antagonize inhibitor of apoptosis proteins. J Biol Chem. 2002; 277(1): 445-454. [PubMed: 11604410]

40. Suzuki Y, Imai Y, Nakayama H, Takahashi K, Takio K, Takahashi R. A serine protease, HtrA2, is released from the mitochondria and interacts with XIAP, inducing cell death. Mol Cell. 2001; 8(3): 613-621. [PubMed: 11583623]

41. Liu Z, Sun C, Olejniczak ET, et al. Structural basis for binding of Smac/DIABLO to the XIAP BIR3 domain. Nature. 2000; 408(6815):1004-1008. [PubMed: 11140637]

42. Martins LM, Iaccarino I, Tenev T, et al. The serine protease Omi/HtrA2 regulates apoptosis by binding XIAP through a reaper-like motif. J Biol Chem. 2002; 277(1):439-444. [PubMed: 11602612]

43. Susin SA, Lorenzo HK, Zamzami N, et al. Molecular characterization of mitochondrial apoptosisinducing factor. Nature. 1999; 397(6718):441-446. [PubMed: 9989411]

44. Li LY, Luo X, Wang X. Endonuclease G is an apoptotic DNase when released from mitochondria. Nature. 2001; 412(6842):95-99. [PubMed: 11452314]

45. Miramar MD, Costantini P, Ravagnan L, et al. NADH oxidase activity of mitochondrial apoptosisinducing factor. J Biol Chem. 2001; 276(19):16391-16398. [PubMed: 11278689]

46. Daugas E, Susin SA, Zamzami N, et al. Mitochondrio-nuclear translocation of AIF in apoptosis and necrosis. Faseb J. 2000; 14(5):729-739. [PubMed: 10744629] 
47. Penninger JM, Kroemer G. Mitochondria, AIF and caspases--rivaling for cell death execution. Nat Cell Biol. 2003; 5(2):97-99. [PubMed: 12563272]

48. Deng Y, Ren X, Yang L, Lin Y, Wu X. A JNK-dependent pathway is required for TNFalphainduced apoptosis. Cell. 2003; 115(1):61-70. [PubMed: 14532003]

49. Bidere N, Lorenzo HK, Carmona S, et al. Cathepsin D triggers Bax activation, resulting in selective apoptosis-inducing factor (AIF) relocation in T lymphocytes entering the early commitment phase to apoptosis. J Biol Chem. 2003; 278(33):31401-31411. [PubMed: 12782632]

50. Dumont C, Durrbach A, Bidere N, et al. Caspase-independent commitment phase to apoptosis in activated blood T lymphocytes: reversibility at low apoptotic insult. Blood. 2000; 96(3):10301038. [PubMed: 10910919]

51. van Gurp M, Festjens N, van Loo G, Saelens X, Vandenabeele P. Mitochondrial intermembrane proteins in cell death. Biochem Biophys Res Commun. 2003; 304(3):487-497. [PubMed: 12729583]

52. Crompton M. The mitochondrial permeability transition pore and its role in cell death. Biochem J. 1999; 341(Pt 2):233-249. [PubMed: 10393078]

53. Adams JM, Cory S. The Bcl-2 protein family: arbiters of cell survival. Science. 1998; 281(5381): 1322-1326. [PubMed: 9735050]

54. Marzo I, Brenner C, Zamzami N, et al. The permeability transition pore complex: a target for apoptosis regulation by caspases and bcl-2-related proteins. J Exp Med. 1998; 187(8):1261-1271. [PubMed: 9547337]

55. Narita M, Shimizu S, Ito T, et al. Bax interacts with the permeability transition pore to induce permeability transition and cytochrome c release in isolated mitochondria. Proc Natl Acad Sci U S A. 1998; 95(25):14681-14686. [PubMed: 9843949]

56. Eskes R, Desagher S, Antonsson B, Martinou JC. Bid induces the oligomerization and insertion of Bax into the outer mitochondrial membrane. Mol Cell Biol. 2000; 20(3):929-935. [PubMed: 10629050]

57. Chipuk JE, Green DR. p53's believe it or not: lessons on transcription-independent death. J Clin Immunol. 2003; 23(5):355-361. [PubMed: 14601643]

58. Chipuk JE, Kuwana T, Bouchier-Hayes L, et al. Direct activation of Bax by p53 mediates mitochondrial membrane permeabilization and apoptosis. Science. 2004; 303(5660):1010-1014. [PubMed: 14963330]

59. Vander Heiden MG, Thompson CB. Bcl-2 proteins: regulators of apoptosis or of mitochondrial homeostasis. Nat Cell Biol. 1999; 1(8):E209-E216. [PubMed: 10587660]

60. Marrack P, Kappler J. Control of T cell viability. Annu Rev Immunol. 2004; 22:765-787. [PubMed: 15032596]

61. Marsden VS, Strasser A. Control of apoptosis in the immune system: Bcl-2, BH3-only proteins and more. Annu Rev Immunol. 2003; 21:71-105. [PubMed: 12414721]

62. Strasser A, Harris AW, Huang DC, Krammer PH, Cory S. Bcl-2 and Fas/APO-1 regulate distinct pathways to lymphocyte apoptosis. Embo J. 1995; 14(24):6136-6147. [PubMed: 8557033]

63. Tamura A, Katsumata M, Greene MI, Yui K. Inhibition of apoptosis and augmentation of lymphoproliferation in bcl-2 transgenic Fas/Fas ligand-defective mice. Cell Immunol. 1996; 168(2):220-228. [PubMed: 8640868]

64. Kyriakis JM, Avruch J. pp54 microtubule-associated protein 2 kinase A novel serine/threonine protein kinase regulated by phosphorylation and stimulated by poly-L-lysine. J Biol Chem. 1990; 265(28):17355-17363. [PubMed: 2170374]

65. Tournier C, Hess P, Yang DD, et al. Requirement of JNK for stress-induced activation of the cytochrome c-mediated death pathway. Science. 2000; 288(5467):870-874. [PubMed: 10797012]

66. Putcha GV, Le S, Frank S, et al. JNK-mediated BIM phosphorylation potentiates BAX-dependent apoptosis. Neuron. 2003; 38(6):899-914. [PubMed: 12818176]

67. Davis RJ. Signal transduction by the JNK group of MAP kinases. Cell. 2000; 103(2):239-252. [PubMed: 11057897]

68. Dong C, Davis RJ, Flavell RA. MAP kinases in the immune response. Annu Rev Immunol. 2002; 20:55-72. [PubMed: 11861597] 
69. Sabapathy K, Kallunki T, David JP, Graef I, Karin M, Wagner EF. c-Jun NH2-terminal kinase (JNK)1 and JNK2 have similar and stage-dependent roles in regulating T cell apoptosis and proliferation. J Exp Med. 2001; 193(3):317-328. [PubMed: 11157052]

70. Manning AM, Davis RJ. Targeting JNK for therapeutic benefit: from junk to gold. Nat Rev Drug Discov. 2003; 2(7):554-565. [PubMed: 12815381]

71. Cheng EH, Wei MC, Weiler S, et al. BCL-2, BCL-X(L) sequester BH3 domain-only molecules preventing BAX- and BAK-mediated mitochondrial apoptosis. Mol Cell. 2001; 8(3):705-711. [PubMed: 11583631]

72. Rincon M, Whitmarsh A, Yang DD, et al. The JNK pathway regulates the In vivo deletion of immature CD4(+)CD8(+) thymocytes. J Exp Med. 1998; 188(10):1817-1830. [PubMed: 9815259]

73. Lei K, Davis RJ. JNK phosphorylation of Bim-related members of the Bcl 2 family induces Baxdependent apoptosis. Proc Natl Acad Sci U S A. 2003; 100(5):2432-2437. [PubMed: 12591950]

74. Sugiyama T, Shimizu S, Matsuoka Y, Yoneda Y, Tsujimoto Y. Activation of mitochondrial voltage-dependent anion channel by apro-apoptotic BH3-only protein Bim. Oncogene. 2002; 21(32):4944-4956. [PubMed: 12118373]

75. Lei K, Nimnual A, Zong WX, et al. The Bax subfamily of Bcl2-related proteins is essential for apoptotic signal transduction by c-Jun NH(2)-terminal kinase. Mol Cell Biol. 2002; 22(13):4929_ 4942. [PubMed: 12052897]

76. Sandalova E, Wei CH, Masucci MG, Levitsky V. Regulation of expression of Bcl-2 protein family member Bim by T cell receptor triggering. Proc Natl Acad Sci U S A. 2004; 101(9):3011-3016. [PubMed: 14970329]

77. Yang DD, Conze D, Whitmarsh AJ, et al. Differentiation of CD4+ T cells to Th1 cells requires MAP kinase JNK2. Immunity. 1998; 9(4):575-585. [PubMed: 9806643]

78. Chen YR, Wang X, Templeton D, Davis RJ, Tan TH. The role of c-Jun N-terminal kinase (JNK) in apoptosis induced by ultraviolet $\mathrm{C}$ and gamma radiation. Duration of JNK activation may determine cell death and proliferation. J Biol Chem. 1996; 271(50):31929-31936. [PubMed: 8943238]

79. Chhabra A. MHC Class I TCR Engineered Anti-Tumor CD4 T Cells: Implications For Cancer Immunotherapy. Endocr Metab Immune Disord Drug Targets. 2009; 9(4):344-352. [PubMed: 19807670]

80. Chhabra A, Yang L, Wang P, et al. CD4+CD25- T cells transduced to express MHC class Irestricted epitope-specific TCR synthesize Th1 cytokines and exhibit MHC class I-restricted cytolytic effector function in a human melanoma model. J Immunol. 2008; 181(2):1063-1070. [PubMed: 18606658]

81. Sadelain M. T-cell engineering for cancer immunotherapy. Cancer J. 2009; 15(6):451-455. [PubMed: 20010162]

82. Bogoyevitch MA, Arthur PG. Inhibitors of c-Jun N-terminal kinases: JuNK no more. Biochim Biophys Acta. 2008; 1784(1):76-93. [PubMed: 17964301]

83. Mukherji B, MacAlister TJ. Clonal analysis of cytotoxic T cell response against human melanoma. J Exp Med. 1983; 158(1):240-245. [PubMed: 6602860]

84. de Vries JE, Spits H. Cloned human cytotoxic T lymphocyte (CTL) lines reactive with autologous melanoma cells. I In vitro generation, isolation, and analysis to phenotype and specificity. J Immunol. 1984; 132(1):510-519. [PubMed: 6197458]

85. Knuth A, Danowski B, Oettgen HF, Old LJ. T-cell-mediated cytotoxicity against autologous malignant melanoma: analysis with interleukin 2-dependent T-cell cultures. Proc Natl Acad Sci U S A. 1984; 81(11):3511-3515. [PubMed: 6610177]

86. Inaba K, Inaba M, Romani N, et al. Generation of large numbers of dendritic cells from mouse bone marrow cultures supplemented with granulocyte/macrophage colony-stimulating factor. J Exp Med. 1992; 176(6):1693-1702. [PubMed: 1460426]

87. Sallusto F, Lanzavecchia A. Efficient presentation of soluble antigen by cultured human dendritic cells is maintained by granulocyte/macrophage colony-stimulating factor plus interleukin 4 and downregulated by tumor necrosis factor alpha. J Exp Med. 1994; 179(4):1109-1118. [PubMed: 8145033] 
88. Mukherji B, Chakraborty NG, Yamasaki S, et al. Induction of antigen-specific cytolytic T cells in situ in human melanoma by immunization with synthetic peptide-pulsed autologous antigen presenting cells. Proc Natl Acad Sci U S A. 1995; 92(17):8078-8082. [PubMed: 7644541]

89. Hsu FJ, Benike C, Fagnoni F, et al. Vaccination of patients with B-cell lymphoma using autologous antigen-pulsed dendritic cells. Nat Med. 1996; 2(1):52-58. [PubMed: 8564842]

90. Gilboa E. DC-based cancer vaccines. J Clin Invest. 2007; 117(5):1195-1203. [PubMed: 17476349]

91. Rosenberg SA, Spiess P, Lafreniere R. A new approach to the adoptive immunotherapy of cancer with tumor-infiltrating lymphocytes. Science. 1986; 233(4770):1318-1321. [PubMed: 3489291]

92. Yee C, Thompson JA, Byrd D, et al. Adoptive T cell therapy using antigen-specific CD8+ T cell clones for the treatment of patients with metastatic melanoma: in vivo persistence, migration, and antitumor effect of transferred T cells. Proc Natl Acad Sci U S A. 2002; 99(25):16168-16173. [PubMed: 12427970]

93. Dudley ME, Wunderlich JR, Yang JC, et al. Adoptive cell transfer therapy following nonmyeloablative but lymphodepleting chemotherapy for the treatment of patients with refractory metastatic melanoma. J Clin Oncol. 2005; 23(10):2346-2357. [PubMed: 15800326]

94. Cole DJ, Weil DP, Shilyansky J, et al. Characterization of the functional specificity of a cloned Tcell receptor heterodimer recognizing the MART-1 melanoma antigen. Cancer Res. 1995; 55(4): 748-752. [PubMed: 7531614]

95. O'Connell J, O'Sullivan GC, Collins JK, Shanahan F. The Fas counterattack: Fas-mediated T cell killing by colon cancer cells expressing Fas ligand. J Exp Med. 1996; 184(3):1075-1082. [PubMed: 9064324]

96. Hildeman DA, Mitchell T, Teague TK, et al. Reactive oxygen species regulate activation-induced T cell apoptosis. Immunity. 1999; 10(6):735-744. [PubMed: 10403648] 


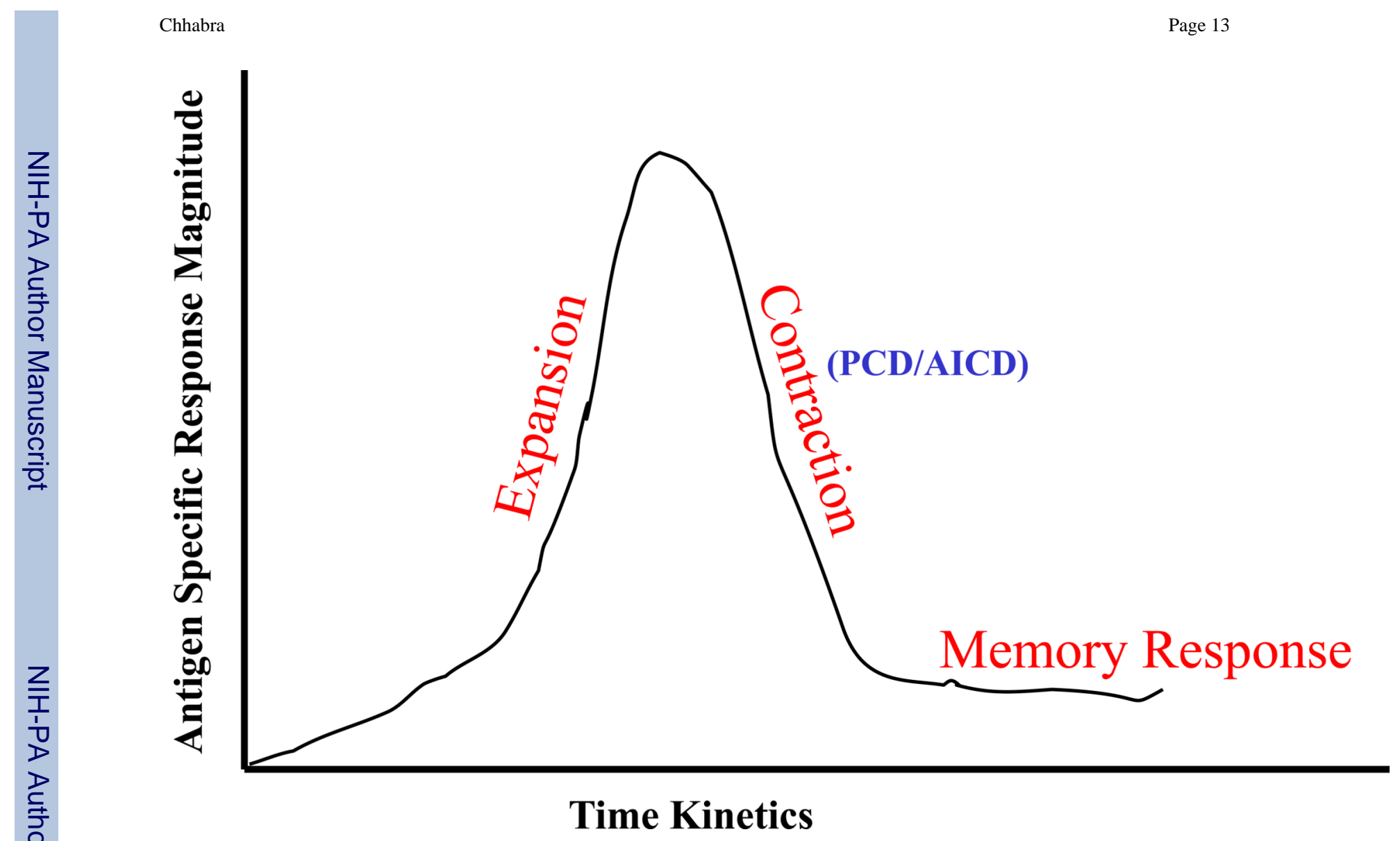

Figure 1. Kinetics of an antigen specific $T$ cell response

As shown an antigen specific $\mathrm{T}$ cell response in comprised of three distinct phases: expansion, contraction, and memory. 
DR-Mediated Caspase-Dependent Cell Death Pathway

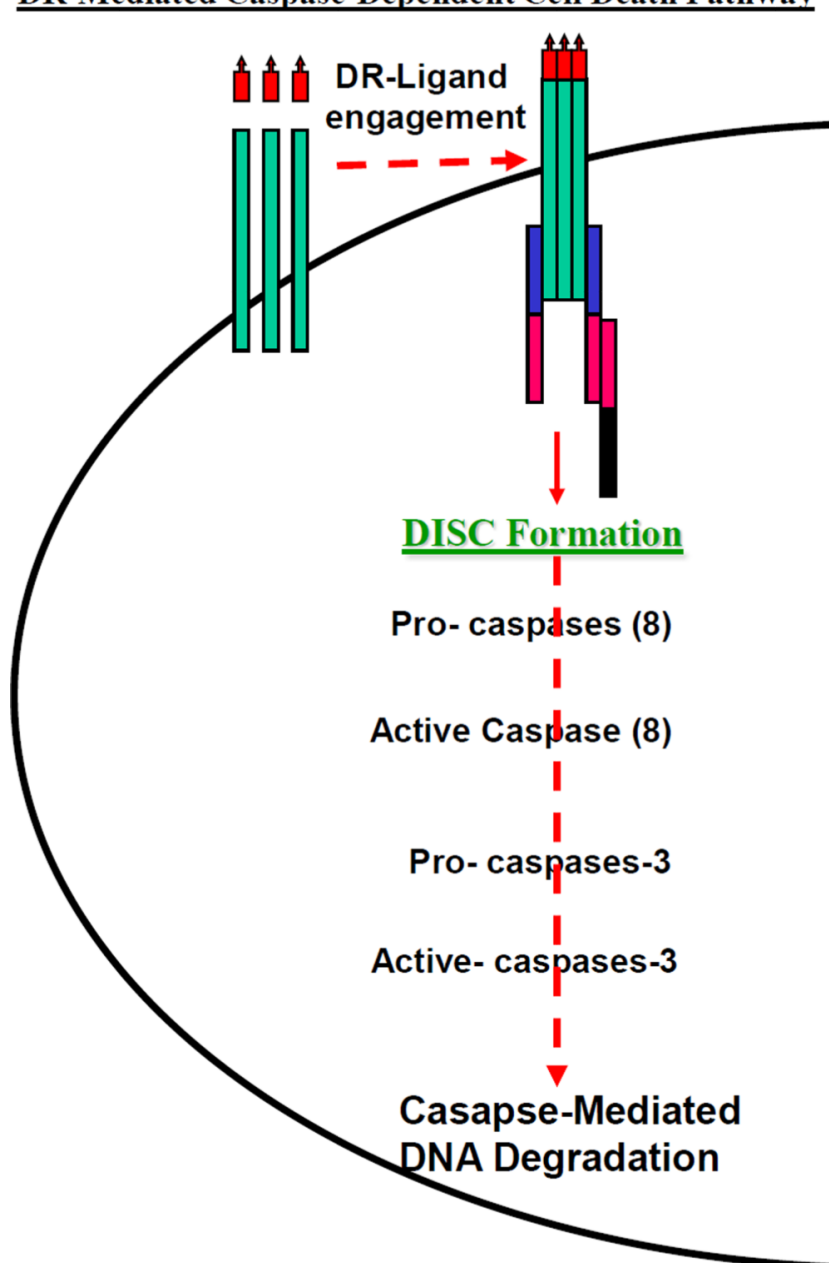

Mitochondria-Centric JNK Driven AICD in Primary CTL

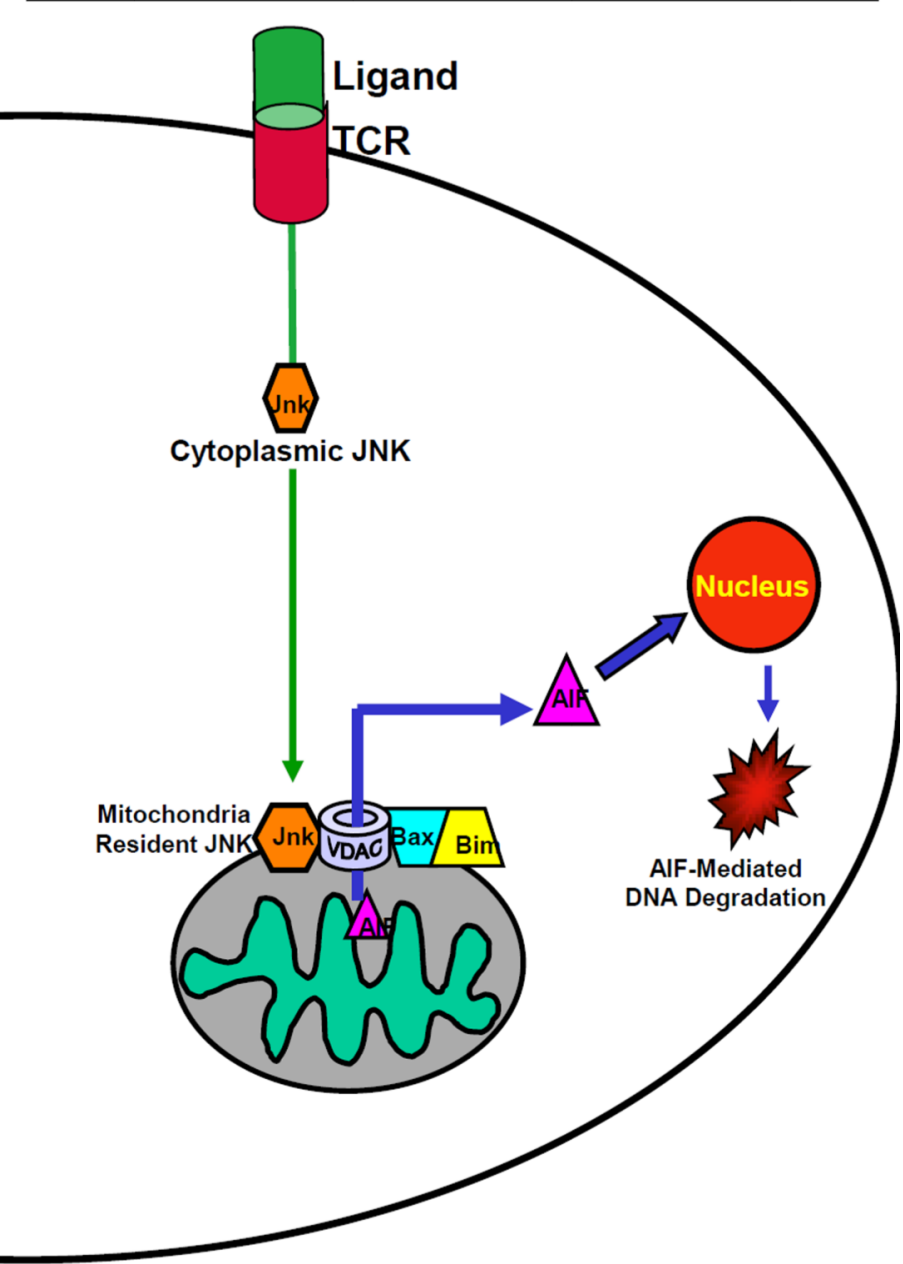

Figure 2. Extrinsic and Intrinsic $\mathbf{T}$ cell death pathways

(Left Panel). The existing paradigm (left panel) states that the T cell death is triggered by the engagement of the surface expressed death receptors (DR) with their corresponding death ligands that leads to the activation of caspases and results in oligosomal DNA degradation mediated cell death. (Right Panel). Recent report suggest that the T cell death, especially the epitope specific activation induced cell death (AICD) in human tumor antigen specific T cells (right panel) is an intrinsic, DR-independent, mitochondria-centric process, in which JNK and mitochondria-resident death executioner, apoptosis inducing factor (AIF) play crucial roles $[9,10]$. 


\section{Table-1}

T Cell Based Cancer Immunotherapy: Key Developments And Current Constraints.

\section{Key Developments:}

- Identification of the first human tumor associated antigen [1].

- $\quad$ Isolation of human tumor associated antigen specific T cell clones [83-85].

- Development of methodologies for a large-scale generation of dendritic cells, in vitro $[86,87]$.

- Development of active specific immunization based cancer immunotherapy strategies [88-90].

- Development of adoptive administration based cancer immunotherapy strategies [91-93].

- Development of TCR engineering based cancer immunotherapy approaches [79-81,94].

\section{Current Constraints:}

- $\quad$ Regulatory T cell mediated immune suppression.

- Immunosuppressive tumor microenvironment and immune dysfunction mechanisms.

- $\quad$ Activation induced cell death (AICD) mediated elimination of anti-tumor T cells, generated in-vivo or ex-vivo expanded administered CTL. 


\section{Table-2}

AICD In T Cells: Death Receptor (DR)-Driven, Caspase Executed Vs Caspase-Independent Pathways.

- Development of the DR-initiated, caspase-executed paradigm on T cell death [14,15,30,31], and the tumor counterattack hypothesis [95].

- $\quad$ Caspase-independent death in T cell $[11,96]$.

- Involvement of mitochondria in cell death pathways [32-34].

- $\quad$ Recent studies supporting the existence of a DR-independent, caspase-independent, mitochondria-centric death pathway in AICD of human anti-tumor T cells $[9,10]$. 